OPTIMUM. STUDIA EKONOMICZNE NR 4 (76) 2015

\author{
Joanna BARAN, Michał PIETRZAK, Piotr PIETRZAK ${ }^{1}$
}

DOI: $10.15290 /$ ose.2015.04.76.11

\title{
EFEKTYWNOŚĆ FUNKCJONOWANIA PUBLICZNYCH SZKÓŁ WYŻSZYCH
}

\begin{abstract}
Streszczenie
Edukacja wyższa jest zaliczana do dóbr merytorycznych (społecznie pożądanych). Ze względu na to, że w wielu krajach rządy interweniują w mechanizm rynkowy wspierając szkolnictwo wyższe, pojawia się istotne pytanie o efektywność sektora publicznego w alokacji rzadkich zasobów gospodarczych. W artykule podjęto dyskusję na temat efektywności publicznych szkół wyższych i metod jej pomiaru, koncentrując uwagę na Data Envelopment Analysis (DEA). Dokonano przeglądu literatury zagranicznej i krajowej w tym zakresie. W artykule zaprezentowano również wyniki wstępnych badań w zakresie wskaźnika efektywności DEA dla trzynastu wydziałów Szkoły Głównej Gospodarstwa Wiejskiego w Warszawie. W badaniach zastosowano model CCR ukierunkowany na maksymalizację efektów. W modelu uwzględniono jedną zmienną po stronie nakładów i trzy zmienne po stronie efektów. Cztery wydziały uznano za w pełni efektywne, zaś pozostałych dziewięć za nieefektywne. Istnieje potrzeba kontynuacji badań na większej, ale wewnętrznie jednorodnej próbie badawczej.
\end{abstract}

Słowa kluczowe: sektor publiczny, szkolnictwo wyższe, efektywność, Data Envelopment Analysis (DEA)

\section{EFFICIENCY PUBLIC HIGHER EDUCATION INSTITUTIONS}

\section{Summary}

Higher education is classified in the category of merit goods. Due to the fact that in many countries, governments interfere in the market mechanism by supporting higher education institutions, there arises an important question of the efficiency of the public sector in the allocation of scarce economic resources. The paper discusses the efficiency of public higher education institutions and its measurement methods, focusing on the non-parametric method - Data Envelopment Analysis. A review of the relevant domestic and international literature is included. The author presents the results of research into the DEA efficiency ratio for thirteen faculties of the Warsaw University of Life Sciences. The analysis was conducted using the CCR model aimed at maximizing effects. The model featured one input and three outputs. Four faculties were found efficient, and the remaining nine - inefficient. There is a need to continue research using alternative methods of measurement.

Key words: public sector, higher education, efficiency, Data Envelopment Analysis (DEA)

\footnotetext{
${ }^{1}$ Dr Joanna Baran - Wydział Nauk Ekonomicznych, Szkoła Główna Gospodarstwa Wiejskiego w Warszawie; e-mail: j.baran.sggw@wp.pl; dr hab. Michał Pietrzak, prof. SGGW - Wydział Nauk Ekonomicznych, Szkoła Główna Gospodarstwa Wiejskiego w Warszawie; e-mail: pietrzakms@poczta.onet.pl; mgr Piotr Pietrzak - Wydział Nauk Ekonomicznych, Szkoła Główna Gospodarstwa Wiejskiego w Warszawie; e-mail: piotr.grzegorz.pietrzak@gmail.com.
} 


\section{Wstęp}

W klasycznym ujęciu Robbinsa ekonomia jest dyscypliną nauki, która bada: ludækeie zachowania jako stosunek miedsy celami i ograniczonymi srodkami o alternatywnych zastosowaniach [Coase, 2013, s. 1]. W związku z tym przyjmuje ona założenie behawioralne o racjonalności ludzkich zachowań, co można sprowadzić do zasady maksymalizacji - ludzie dazżą do tego, by osiagnąć cel, zużywając w ten sposób najmniejszą możliwą ilość nakładów. Kluczowym pojęciem ekonomii jest zatem efektywność, przy czym ocena efektywności dotyczy alokacji rzadkich zasobów pomiędzy alternatywne zastosowania [Gorynia i in. 2005, s. 596]. Decyzje alokacyjne mogą się dokonywać za pośrednictwem mechanizmu rynkowego lub przez podmioty sektora publicznego. Podmioty sektora publicznego stanowia istotny element polskiej gospodarki. Co piąty zatrudniony Polak pracuje w sektorze publicznym, a wydatki na ten sektor przekraczaja $40 \%$ PKB. Naturalne staje się więc pytanie o efektywność sektora publicznego jako alokatora zasobów gospodarczych.

Szczególnym obszarem zaangażowania sektora publicznego jest edukacja, w tym szkolnictwo wyższe. Jeśli uzna się że głównym celem każdego społeczeństwa jest wysoki i rosnący poziom życia, to kluczową determinantą tego celu jest rosnąca produktywność [Porter, 1992, s. 6]. Warunkiem wzrostu produktywności jest dostęp do ponadprzeciętnych czynników produkcji, przy czym produkcja niektórych z nich jest postrzegana w kategoriach pozytywnych efektów zewnętrznych - dostarcza korzyści gospodarczych, które przekraczają korzyści indywidualne z inwestycji w ich produkcję. Do tej grupy czynników produkcji zalicza się wyspecjalizowane zasoby ludzkie i wiedzę naukowa - co może stanowić uzasadnienie dla zaangażowania sektora publicznego w ich dostarczanie [Porter, 1992, s. 626-637].

$\mathrm{Z}$ drugiej strony podmioty sektora publicznego są często postrzegane jako mniej skuteczne i efektywne w porównaniu z biznesem. Jednakże w miarę wzrostu znaczenia sektora publicznego w gospodarce, społeczeństwa nie chcą dłużej tolerować zbiurokratyzowanych, nieelastycznych, nieefektywnie wykorzystujących zasoby instytucji. Wskutek tego, podmioty sektora publicznego sa poddawane coraz silniejszej presji związanej z naśladowaniem efektywności przedsiębiorstw [Ansoff, 1985, s. 30]. Na przełomie lat siedemdziesiątych i osiemdziesiątych ubiegłego wieku wyłoniła się koncepcja New Public Management (NPM) - Nowego Zarządzania Publicznego [Hood, 1991, s. 3-4; O'Flynn, 2007, s. 353]. Zgodnie z idea NPM, organizacje sektora publicznego powinny dążyć do efektywności i elastyczności firm sektora biznesu, w szczególności przez: implementację mechanizmów konkurowania, orientację na klienta, decentralizację, pomiar osiagnięć, zarządzanie strategiczne. W ostatnich latach system edukacji wyższej stał się obszarem aplikacji koncepcji New Public Management [Schimank, 2005, s. 362; Tahar, 2013, s. 687], zwłaszcza w Europie, gdzie - jak podaja Wilkesman i Schmid - we wszystkich krajach zarządzanie uniwersytetami przesuwa się w kierunku NPM [Wilkesman, Schmid, 2012, s. 34].

Autorzy niniejszego artykułu postawili przed sobą dwa cele. Pierwszym celem jest dyskusja nad problemem efektywności i jej pomiaru w odniesieniu do publicznych 
szkół wyższych. Drugim celem jest zaprezentowanie wstępnych wyników badań efektywności z zastosowaniem metody Data Envelopment Analysis na przykładzie trzynastu wydziałów największej uczelni przyrodniczej w Polsce - Szkoły Głównej Gospodarstwa Wiejskiego w Warszawie.

\section{Przegląd literatury}

Przyjmując za Gorynią i innymi, że Ekonomia zajmuje sie efektywnościa rynków w alokacji $i$ koordynacji zastosowań zasobów [Gorynia i in. 2005, s. 596], warto zastanowić się nad problemem zasadności zastapienia mechanizmu rynkowego państwem jako alokatorem zasobów w przypadku szkolnictwa wyższego. Edukacja wyższa nie spełnia kryteriów definicyjnych dobra publicznego, takich jak brak konkurencyjności i brak możliwości wyłaczenia z konsumpcji [Fijor, 2011, s. 96-97]. Jest ona zaliczana do tzw. dóbr merytorycznych [Powell, 2005, s. 147].

Autor koncepcji dóbr merytorycznych - Musgrave definiuje je jako dobra, które są: na tyle ważne, ze gdy ich konsumpcja na wolnym rynku jest na nienystarczajacym poziomie, kompetentne władze interweniuja, by te konsumpije apiekessyć, nawet wbrew preferencjom konsumentów [Musgrave, 1987, s. 452-453]. Konsumpcja dóbr merytorycznych generuje nie tylko korzyści indywidualne, ale również w ich następstwie korzyści społeczne, które stanowia efekty zewnętrzne konsumpcji indywidualnej [Mucha, 2006, s. 13]. Lepiej wyedukowani obywatele zarabiają więcej, ale także przyczyniaja się do wzrostu całej gospodarki. Oczywiście, otwarte pozostają na przykład poniżej wymienione problemy.

1. Jak określić, czy dostępność edukacji wyższej jest lub nie jest na „wystarczającym poziomie" i czy w związku z tym interwencja państwa jest potrzebna?

2. Jaka powinna być skala interwencji państwa w system szkolnictwa wyższego - zarówno w wymiarze finansowania, jak i w wymiarze centralizacji decyzji $\mathrm{i}$ ingerencji w funkcjonowanie systemu?

3. Czy zjawiska ignorancji politycznej i pogoni za rentami politycznymi umożliwiają merytoryczną odpowiedź na powyższe pytanie? Czy pozwalają adekwatnie do realnych potrzeb kształtować ofertę edukacyjną? Jeśli - nie, to czy problemy z tym związane nie przekraczaja potencjalnych korzyści wynikających z interwencji państwa zwiększającej konsumpcję dobra merytorycznego?

4. Sektor publiczny nie produkuje ani najlepiej, ani najefektywniej [Bowden, Bowden, 2002, s. 698]. Czy niższa efektywność i elastyczność w stosunku do prywatnych przedsiębiorstw oraz biurokratyczna niewydolność organizacji sektora publicznego - w tym wypadku uczelni publicznych - nie niweczą potencjalnych korzyści wynikających z interwencji państwa zwiększającej konsumpcję dobra merytorycznego?

Niezależnie od odpowiedzi na powyższe pytania, faktem pozostaje istotne zaangażowanie państwa w system edukacji wyższej w wielu krajach. W ostatnich latach uniwersytety, tak jak i inne podmioty sektora publicznego, zaczęły wdrażać założenia koncepcji New Public Management [Schimank, 2005, s. 362]. New Public Managment 
jako podejście do zarządzania w sektorze publicznym jest stosowany w systemach edukacji wyższej wielu krajów zachodnich [Tahar, 2013, s. 687]. Szczególnie w Europie zarządzanie uniwersytetami w ostatnim okresie ewoluuje w kierunku Nowego Zarządzania Publicznego [Wilkesman, Schmid, 2012, s. 34]. Wdrażane są rozwiązania pochodzące z sektora prywatnego, takie jak: definiowanie docelowych poziomów w zakresie skuteczności i efektywności, benchmarking, pomiar osiagnięć (dokonań), odpowiedzialność i motywacja poprzez bodźce płacowe [Parker, 2012, s. 250].

Jeśli mówi się o pomiarze osiagnięć, docelowej efektywności, benchmarkingu, to powstaje istotne pytanie o sposób mierzenia efektywności w publicznym szkolnictwie wyższym. Biorąc pod uwagę specyfikę sektora publicznego, trudno jest bezpośrednio przenosić wzorce pomiaru i oceny z sektora prywatnego. Z drugiej strony, uwzględniając konieczność efektywnej alokacji środków publicznych, potrzebne są metody i narzędzia porównywania i oceny jednostek sektora publicznego.

Mówiąc o efektywności publicznych szkół wyższych, autorzy mają na myśli relację między rezultatami (efektami) - odnoszącymi się do kluczowych obszarów funkcjonowania uczelni (dydaktyki, badań, działalności upowszechnieniowej) - a nakładami finansowymi, rzeczowymi, w szczególności ludzkimi zaangażowanymi w ich uzyskanie.

Ze względu na konieczność uwzględnienia wielu efektów i nakładów, w literaturze zagranicznej dotyczącej pomiaru efektywności w sektorze publicznym znacząca pozycję zajmuje metoda Data Envelopment Analysis (DEA). Była ona wykorzystywana do badania efektywności szpitali i innych jednostek leczniczych [Por. m.in.: Färe i in. 1992, s. 85-101; Hollingsworth $i$ in. 1999, s. 161-172; Jacobs, 2001, s. 103-115], uczelni wyższych [Por. m.in.: Bates, 1993, s. 277-289; Thanassoulis, Dunstan, 1994, s. 12471262; Chakraborty i in. 2001, s. 889-905; Saunders, 2003, s. 5-14; Kao, Hung, 2008, s. 653664], jednostek wojskowych [Por. Sun, 2004, s. 233-245], a także organizacji typu nonprofit, np.: bibliotek, instytucji charytatywnych. Stosowanie metody DEA do oceny efektywności instytucji sektora publicznego jest uzasadniane możliwościa przeprowadzenia wielokryterialnej oceny działalności z uwzględnieniem w analizie różnych zmiennych o charakterze nakładów i efektów.

Metoda Data Envelopment Analysis (DEA) 2 jest zaliczana do nieparametrycznych metod badania efektywności obiektów. W 1978 roku autorzy metody DEA (Charnes, Cooper i Rhodes) bazując na koncepcji produktywności sformułowanej przez Debreu i Farella, definiującej miarę produktywności jako iloraz pojedynczego efektu i pojedynczego nakładu, zastosowali ją do sytuacji wielowymiarowej, to jest takiej, w której dysponuje się więcej niż jednym nakładem $i$ więcej niż jednym efektem [Charnes $i$ in. 1994, s. 513]. Matematycznie model DEA można przedstawić w następujący sposób ${ }^{3}$ [Charnes i in. 1994, s. 513]:

\footnotetext{
2 Polskie odpowiedniki nazwy metody - choć rzadko używane - to: analiza obwiednich danych, analiza otoczki danych, graniczna analiza danych.

${ }^{3}$ Prezentowane wzory dotyczą modelu znanego w literaturze pod nazwą CCR i zorientowanego na minimalizację nakładów.
} 
funkcja celu:

$$
\max _{u, v} \frac{\sum_{r=1}^{s} \mu_{r} y_{r o}}{\sum_{i=1}^{m} v_{i} x_{i o}}
$$

przy następujących warunkach ograniczających:

$$
\begin{gathered}
\frac{\sum_{r=1}^{s} \mu_{r} y_{r j}}{\sum_{i=1}^{m} v_{i} x_{i j}} \leq 1 \quad(j=0,1, \ldots, n), \\
\mu_{r}, v_{i} \geq 0, \\
\frac{\mu_{r}}{\sum_{i=1}^{m} v_{i} x_{i o}} \geq \varepsilon \quad \text { dla } \quad r=0,1, \ldots, s, \\
\frac{v_{i}}{\sum_{i=1}^{m} v_{i} x_{i o}} \geq \varepsilon \quad \text { dla } \quad r=0,1, \ldots, m,
\end{gathered}
$$

gdzie:

$s-$ liczba efektów,

$m$ - liczba nakładów,

$\mu_{r}$ - wagi określające ważność poszczególnych efektów,

$v_{i}$ - wagi określające ważność poszczególnych nakładów,

$y_{r j}$ - wielkość efektu $r$-tego rodzaju $(r=1, \ldots, \mathrm{R})$ w obiekcie $j$-tym,

$x_{i j}$ - wielkość nakładu $i$-tego rodzaju $(n=1, \ldots, \mathrm{N})$ w obiekcie $j$-tym; $(j=1, \ldots, J)$.

Metoda DEA umożliwia badanie relacji między poziomem wielu nakładów a wielu efektów. W modelu DEA $m$ nakładów i $s$ różnych efektów sprowadzonych zostaje do pojedynczych wielkości „syntetycznego” nakładu i „syntetycznego” efektu, które następnie są wykorzystywane przy obliczaniu wskaźnika efektywności obiektu [Roll, Hayuth, 1993, s. 154-156]. W programowaniu liniowym wskaźnik ten jest funkcja celu. W metodzie DEA można wyróżnić dwa warianty funkcji celu: maksymalizację efektów przy danych nakładach lub minimalizację nakładów przy danych efektach [Cooper i in. 2007, s. 70].

Zmiennymi optymalizowanymi są współczynniki $\mu_{r}$ i $\nu_{\mathrm{i}}$ będące wagami wielkości nakładów i efektów, a wielkości efektów oraz nakładów są danymi empirycznymi [Cooper i in. 2007, s. 72-75]. Ograniczenie zakłada, że iloraz syntetycznego efektu i syntetycznego nakładu ma być mniejszy lub równy jedności, bez tego ograniczenia zadanie miałoby nieskończenie wiele rozwiązań. Wagi nakładów i efektów są wyznaczone w taki sposób, aby maksymalizowały powyższą relację efektów do nakładów, a ich 
wielkości mogą być równe albo większe od zera. Rozwiązanie funkcji celu przy pomocy programowania liniowego pozwala na ustalenie krzywej efektywności, na której znajdują się wszystkie najbardziej efektywne jednostki badanej zbiorowości ${ }^{4}$ (rysunek 1.).

RYSUNEK 1.

Krzywe efektywności CCR (o stałych efektach skali) i BCC (o zmiennych efektach skali), (model: 1 efekt i 1 nakład)

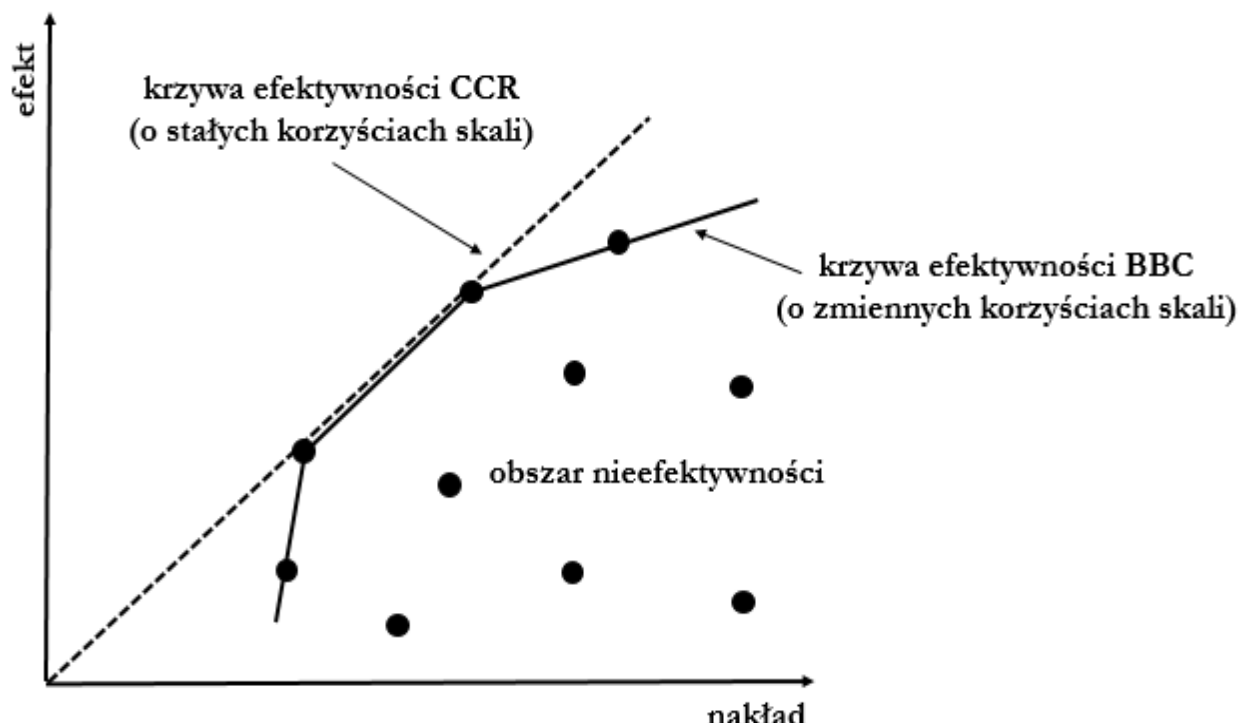

Źródło: opracowanie własne.

Obiekty uważa się za efektywne technicznie, jeżeli znajdują się na krzywej efektywności (wskaźnik ich efektywności wynosi 1, co w modelu ukierunkowanym na minimalizację nakładów oznacza, że nie istnieje bardziej korzystna kombinacja nakładów pozwalająca na osiagnięcie przez przedsiębiorstwo tych samych efektów), natomiast jeśli znajdują się poza krzywą efektywności, są nieefektywne technicznie (wskaźnik ich efektywności jest mniejszy od 1, co oznacza, że istnieje bardziej efektywna kombinacja nakładów umożliwiająca osiagnięcie tych samych efektów). Efektywność obiektu jest mierzona względem innych obiektów $z$ badanej grupy i przyjmuje wartości z przedziału $(0,1)$. W metodzie DEA obiektami analizy są tzw. jednostki decyzyjne - Decision Making Units (DMU) [Charnes i in. 1994, s. 514]. Przedmiotem analizy jest efektywność, z jaką dana DMU transformuje posiadane nakłady w wyniki.

\footnotetext{
${ }^{4}$ Graficzna prezentacja krzywej efektywności jest możliwa dla modeli: 1 nakład i 1 efekt, 2 nakłady i 1 efekt lub 1 nakład i 2 efekty. Dla modeli wielowymiarowych odpowiednikiem krzywej jest kilka połączonych ze sobą fragmentów różnych hiperpłaszczyzn.
} 
Metoda DEA umożliwia porównanie (benchmarking) danego obiektu z najlepszymi z branży oraz pozwala na ustalenie technologii optymalnej dla nieefektywnego obiektu, która jest określana na podstawie technologii obiektów o najwyższej względnej efektywności w badanej grupie. Technologia optymalna jest wyznaczana na podstawie wzoru [Guzik 2009, s. 38]:

$$
T^{*}{ }_{0}=\sum_{j=1}^{N} \lambda_{o j} \cdot t_{j}(2),
$$

$T^{*}$ - technologia optymalna dla $o$-tego obiektu,

$t j$ - technologia empiryczna $j$-tego obiektu,

$\lambda \circ j$ - udział technologii $j$-tego obiektu w technologii optymalnej dla $o$-tego obiektu.

Należy podkreślić, że sami twórcy metody DEA zaprezentowali ją na przykładzie oceny programu w dziedzinie szkolnictwa [Por. Charnes, Cooper, Rhodes, 1981, s. 668-697]. Dokładny przegląd literatury dotyczącej pierwszych badań w zakresie edukacji wykorzystujących metody nieparametryczne można odnaleźć w artykule Worthingtona z 2001 roku. Opisuje on głównie prace nad efektywnością szkół podstawowych i średnich, które zostały opublikowane w okresie od 1981 do 1998 roku. Porusza on także tematykę oceny efektywności wydziałów i uniwersytetów, przywołując m.in. badania Athanassopoulosa i Shale'a z 1997 roku [Wolszczak-Derlacz, 2013, s. 33]. Dotychczasowe badania nad efektywnością szkół wyższych były prowadzone przede wszystkim w obrębie jednego kraju i jednego roku. Jest to uzasadnione, gdy weźmie się pod uwage, że nie funkcjonuje uniwersalny system szkolnictwa wyższego, a różne kraje posiadają systemy o zróżnicowanych cechach [Por. Wolszczak-Derlacz, 2013, s. 33]. Nieliczne z krajów zostały dogłębnie przebadane, np.: Niemcy [Warning, 2004, s. 393-408], Austria [Leitner i in., 2007, s. 517-538]. Wyrazem wzrostu zainteresowania tą tematyką sa prace analizujące efektywność szkolnictwa wyższego w takich krajach, jak: Turcja [Celik, Ecer, 2009, s. 614-634] czy Chiny [Johnes, Yu, 2008, s. 679-696].

W tabeli 1. przedstawiono wybrane prace empiryczne wykorzystujące metodę DEA do oceny efektywności szkolnictwa wyższego. Wyniki badań wskazują że nie ma uniwersalnego zestawu zmiennych wchodzących w skład nakładów i wyników. Ich dobór często jest limitowany dostępnością danych oraz wynika z doświadczeń z poprzednich badań. Wśród nakładów najczęściej są wykorzystywane: liczba pracowników naukowo-dydaktycznych, liczba pracowników niebędących pracownikami naukowymi, a także nakłady finansowe. $Z$ kolei do miar zaliczanych do wyników należą: liczba publikacji, liczba absolwentów oraz liczba nadanych stopni naukowych. Jak wskazuje Wolszczak-Derlacz, problematyczna zmienna to liczba studentów [Wolszczak-Derlacz, 2013, s. 35]. Mancebon i Bandres podkreślaja, że liczba studentów nie jest normalnym zasobem i dlatego nie może być miarą nakładów [Mancebon, Bandres, 1999, s. 131-152]. Natomiast Morawski nazywa studentów „półproduktem” [Morawski, 1999, s. 140$-141]$. 
TABELA 1.

Zestawienie wybranych prac empirycznych w literaturze światowej wykorzystujących metodę DEA w ocenie efektywności szkół wyższych

\begin{tabular}{|c|c|c|c|c|}
\hline Lp. & $\begin{array}{c}\text { Autor } \\
\text { i rok }\end{array}$ & $\begin{array}{l}\text { Zakres ba- } \\
\text { dań }\end{array}$ & Nakłady (N)/Efekty (E) & Wnioski \\
\hline 1. & $\begin{array}{l}\text { Carring- } \\
\text { ton } \mathrm{i} \text { in. } \\
(2005)\end{array}$ & $\begin{array}{l}35 \text { uniwer- } \\
\text { sytetów } \\
\text { z Australii, } \\
1996-2000\end{array}$ & $\begin{array}{l}\text { N: koszty operacyjne } \\
\text { E: ważona liczba publikacji, } \\
\text { liczba studentów, liczba stu- } \\
\text { dentów kończących studia }\end{array}$ & $\begin{array}{l}\text { Największy wpływ na efektyw- } \\
\text { ność ma położenie uniwersy- } \\
\text { tetu i procent studentów po- } \\
\text { chodzacych ze wsi i odda- } \\
\text { lonych obszarów. Z tym że } \\
\text { uniwersytety zlokalizowane } \\
\text { poza metropoliami mają wyż- } \\
\text { szą efektywność - gdyż sa } \\
\text { niższe koszty pracy. }\end{array}$ \\
\hline 2. & $\begin{array}{l}\text { Celiki } \\
\text { Ecer } \\
(2009)\end{array}$ & $\begin{array}{l}35 \text { uniwer- } \\
\text { sytetów w } \\
\text { Turcji }\end{array}$ & $\begin{array}{l}\text { N: liczba studentów, liczba } \\
\text { pracowników naukowych } \\
\text { i administracyjnych, procent } \\
\text { studentów rachunkowości, } \\
\text { procent pracowników ra- } \\
\text { chunkowości, minimalne wy- } \\
\text { niki z egzaminów wstępnych } \\
\text { E: wyniki z egzaminu Selec- } \\
\text { tion Exam for Public Personnel }\end{array}$ & $\begin{array}{l}\text { Uczelnie w Turcji w sposób } \\
\text { efektywny wykładają rachun- } \\
\text { kowość; heterogeniczność } \\
\text { na poziomie wydziałów. }\end{array}$ \\
\hline 3. & $\begin{array}{c}\text { Leitner } \\
\mathrm{i} \text { in. }(2007)\end{array}$ & $\begin{array}{l}10 \text { uniwer- } \\
\text { sytetów } \\
\text { z Austrii, } \\
2000-2001\end{array}$ & $\begin{array}{l}\text { N: nauczyciele akademiccy, } \\
\text { powierzchnia wydziału } \\
\text { E: oceny z egzaminów, prace } \\
\text { dyplomowe, absolwenci, pu- } \\
\text { blikacje w czasopismach, } \\
\text { monografie, patenty, przy- } \\
\text { chody ze źródeł trzecich }\end{array}$ & $\begin{array}{l}\text { Efektywność jest uzależnio- } \\
\text { na od dyscypliny nauki, a wy- } \\
\text { działy w tych samych dyscy- } \\
\text { plinach z różnych uniwersy- } \\
\text { tetów różnią się efektywno- } \\
\text { ścią. }\end{array}$ \\
\hline 4. & $\begin{array}{l}\text { Warning } \\
\text { (2004) }\end{array}$ & $\begin{array}{l}73 \text { wyższe } \\
\text { uczelnie pu- } \\
\text { bliczne } \\
\text { z Niemiec, } \\
\text { 1997-1999 }\end{array}$ & $\begin{array}{l}\text { N: wydatki osobowe, wydat- } \\
\text { ki pozaosobowe } \\
\text { E: publikacje ISI, absolwenci } \\
\text { według dziedzin }\end{array}$ & $\begin{array}{l}\text { Efektywność dla modelu dy- } \\
\text { daktycznego jest wyższa niż } \\
\text { dla modelu badawczego. }\end{array}$ \\
\hline
\end{tabular}

Źródło: [Wolszczak-Derlacz 2013, s. 150-152].

Kwestia pomiaru efektywności uczelni jest obecnie szczególnie istotna w Polsce, w kontekście wyzwań strategicznych, z jakimi musi zmierzyć się system szkolnictwa wyższego [Pietrzak, 2013a, s. 406-409]. Pomimo dużej popularności metody DEA, w Polsce przypadki jej stosowania do oceny efektywności szkół wyższych są nieliczne [Nazarko i in., 2008, s. 89-105]. Świttyk i Pasewicz przedstawili wyniki analizy efektywności wyższych szkół zawodowych. Wykazały one, że jest to grupa o stosunkowo wysokiej efektywności technicznej [Świtłyk, Pasewicz, 2009, s. 187-196]. Z kolei w publikacji z 2010 roku autorzy ci podjęli próbę oceny efektywności 59 uczelni publicznych dla lat 2006-2008. Jako nakłady przyjęto płace brutto oraz sumę pozostałych kosztów według rodzaju, a za wyniki działalności uczelni - sumę funduszy uzyskanych na badania oraz liczbę studentów studiów stacjonarnych i niestacjonarnych. Przy tak określonym 
zbiorze zmiennych najwyższą efektywnością charakteryzowały się uczelnie techniczne, pedagogiczne i uniwersytety [Pasewicz, Świtłyk, 2010, s. 87-98].

Ćwiąkała-Małys przeanalizowała pięć modeli DEA $z$ wykorzystaniem danych pochodzących z 59 uczelni publicznych z lat 2001-2007 [Ćwiąkała-Małys, 2009, s. 144-145]. Do zbioru nakładów zostały włączone następujące zmienne: liczba pracowników naukowo-dydaktycznych, liczba pracowników niebędących nauczycielami akademickimi, koszty operacyjne, majątek trwały, koszty poza kosztami pracy, wysokość dotacji dydaktycznej. Do zmiennych po stronie wyników procesu kształcenia zaliczono: liczbę studentów oraz liczbę absolwentów. Dokonano obliczeń zarówno przy założeniu stałych, jak i zmiennych efektów skali. Na podstawie otrzymanych wyników wyodrębniono cztery grupy uczelni: uczelnie ze wskaźnikiem efektywności powyżej średniej i z dotacją powyżej średniej (uniwersytety), uczelnie o efektywności poniżej średniej i dotacji powyżej średniej (głównie uczelnie techniczne), uczelnie o efektywności powyżej średniej i dotacji poniżej średniej (wszystkie uczelnie pedagogiczne oraz ekonomiczne), uczelnie o efektywności mniejszej niż średnia przy dotacji także niższej niż średnia (szkoły rolnicze oraz akademie wychowania fizycznego). Ponadto autorka przedstawiła propozycję modyfikacji algorytmu dotacyjnego o składnik efektywności wykorzystania zasobów [Ćwiąkała-Małys, 2009].

\section{Materiał i metody}

Jak wynika z cytowanych wyżej badań Ćwiąkały-Małys, efektywność szkół wyższych $\mathrm{w}$ Polsce jest powiązana $\mathrm{z}$ profilem uczelni. Wskazuje to na potrzebę badań uwzględniających profil kształcenia. Zainteresowania Autorów koncentrują się na uczelniach przyrodniczych, dlatego w niniejszym badaniu, które ma charakter pilotażowy, dokonano doboru celowego - Szkoły Głównej Gospodarstwa Wiejskiego w Warszawie, która jest największą uczelnią przyrodniczą w Polsce. Materiałem źródłowym do badań były dane 13 wydziałów SGGW. W Szkole Głównej Gospodarstwa Wiejskiego w Warszawie studiuje 1,4\% ogółu wszystkich studentów w Polsce, co stanowi 28\% studentów uczelni przyrodniczych. Zatrudnia ona $23 \%$ pracowników naukowych i kształci $32 \%$

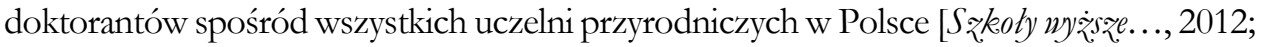
Sprawozdanie Rektora..., 2013]. W odniesieniu do SGGW badania maja charakter pełny i dotyczą wszystkich trzynastu wydziałów tej uczelni:

1. Rolnictwa i Biologii,

2. Medycyny Weterynaryjnej,

3. Leśnego,

4. Ogrodnictwa, Biotechnologii i Architektury Krajobrazu,

5. Budownictwa i Inżynierii Srodowiska,

6. Technologii Drewna,

7. Nauk o Zwierzętach,

8. Nauk o Żywności,

9. Nauk o Żywieniu Człowieka i Konsumpcji,

10. Inżynierii Produkcji, 
11. Nauk Ekonomicznych,

12. Nauk Humanistycznych,

13. Zastosowań Informatyki i Matematyki.

W analizie efektywności wydziałów wykorzystano materiały wewnętrzne SGGW pochodzące ze sprawozdań rektorów z działalności uczelni. Efektywność mierzono na podstawie metody DEA omówionej w przeglądzie literatury, przy czym do określenia efektywności poszczególnych wydziałów Szkoły Głównej Gospodarstwa Wiejskiego w Warszawie zastosowano model CCR ukierunkowany na maksymalizację efektów (output-oriented).

Definiując efekty, uwzględniono współczesny trend ewolucji roli uniwersytetów polegający na odchodzeniu od koncepcji uniwersytetu homboldtowskiego (liberalnego) w kierunku koncepcji uniwersytetu przedsiębiorczego [Por. Leja, 2013, s. 55]. Wiaże się to z rozszerzeniem tradycyjnej misji obejmującej kształcenie i badania naukowe o trzeci filar, jakim jest rozwój ekonomiczny i społeczny otoczenia [Leja, 2013, s. 60-61]. Trend ten znajduje swoje odzwierciedlenie również w zapisach Strategii SGGW do 2020 roku, w której podkreśla się potrzebę silniejszej więzi z praktyka gospodarczą i dażenie do tego, by transfer wiedzy do gospodarki stał się znaczącym filarem działalności SGGW [Pietrzak, 2013b, s. 6, s. 8]. Dlatego też, definiując efekty w modelu DEA, wzięto pod uwagę trzy zmienne odnoszące się do wspomnianych trzech filarów misji uniwersytetu przedsiębiorczego (oczywiście w zakresie, w jakim pozwalała na to ograniczona dostępność danych):

1. Efekt $\mathbf{y}_{1}$ - odzwierciedlający aktywność wydziałów w zakresie procesów kształcenia (liczba studentów w osobach);

2. Efekt $\mathbf{y}_{2}$ - określający aktywność naukową wyrażoną w formie publikacji pracowników wydziałów (liczba punktów za publikacje);

3. Efekt $\mathbf{y}_{3}$ - obrazujący przedsiębiorczość wydziałów w pozyskiwaniu środków zewnętrznych w postaci grantów badawczych oraz prac zleconych realizowanych przez pracowników „pod szyldem” uczelni - tzw. KZL (łączna wartość grantów i prac zleconych w zł).

Ze względu na niewielką liczbę obiektów liczba zmiennych nie powinna być zbyt duża, dlatego przyjąwszy trzy zmienne po stronie efektów, uwzględniono tylko jedną zmienną po stronie nakładów. Przy takim ograniczeniu uznano, że najbardziej kluczowym nakładem są ludzie, a w szczególności kadra akademicka. Za nakład x 1 przyjęto liczbę nauczycieli akademickich (w osobach). Dla takiej struktury nakładów i efektów jest uzasadnione przyjęcie orientacji modelu ukierunkowanej na maksymalizację efektów - strategia uczelni nie zakłada redukcji potencjału kadrowego wydziałów. W takich uwarunkowaniach efektywność wydziałów raczej powinna poprawiać się dzięki aktywizacji pracowników niż redukcji zatrudnienia.

W procesie przetwarzania materiału badawczego wykorzystano arkusz kalkulacyjny Microsoft Excel 2007 oraz program DEA Solver Pro. 


\section{Wyniki badań}

W tabeli 2. przedstawiono syntetyczną charakterystykę SGGW w przekroju czterech zmiennych uwzględnionych w modelu DEA. Bazując na wynikach modelu, określono efektywność poszczególnych wydziałów i na tej podstawie stworzono ich ranking (rysunek 2.). Średnia wartość wskaźnika efektywności DEA dla wydziałów SGGW w 2012 roku wyniosła 0,80. Cztery wydziały (Nauk Ekonomicznych, Technologii Drewna, Leśny, Medycyny Weterynaryjnej) z 13 badanych uznano za w pełni efektywne, a ich wskaźnik efektywności wyniósł jeden (rysunek 2.). Wskaźnik efektywności dla pozostałych wydziałów kształtował się w przedziale od 0,44 do 0,97. Najniższą efektywnością charakteryzowały się wydziały: Zastosowań Informatyki i Matematyki oraz Budownictwa i Inżynierii Środowiska.

TABELA 2.

Charakterystyka SGGW według zmiennych uwzględnionych w modelu DEA

\begin{tabular}{|c|c|c|c|c|}
\hline Wyszczególnienie & $\begin{array}{c}\text { Liczba nau- } \\
\text { czycieli akade- } \\
\text { mickich } \\
\text { (os.) }\end{array}$ & $\begin{array}{c}\text { Liczba stu- } \\
\text { dentów } \\
\text { (os.) }\end{array}$ & $\begin{array}{c}\text { Liczba punk- } \\
\text { tów za publi- } \\
\text { kacje (pkt) }\end{array}$ & $\begin{array}{c}\text { Wartość } \\
\text { Grantów + KZL } \\
\text { (z1) }\end{array}$ \\
\hline Minimum & 54 & 635 & 619 & 51717 \\
\hline Średnia & 95 & 1822 & 1681 & 1415576 \\
\hline Maksimum & 131 & 5317 & 3114 & 4552443 \\
\hline
\end{tabular}

Źródło: opracowanie własne.

RYSUNEK 2.

Wskaźniki efektywności DEA dla wydziałów SGGW w Warszawie (2012 rok)

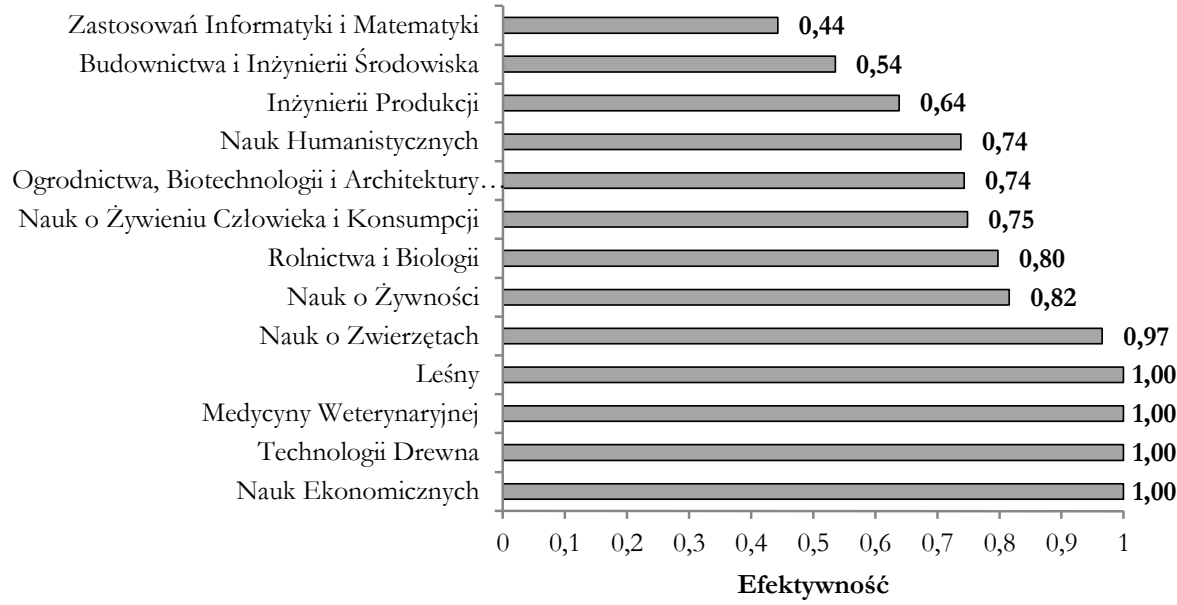

Źródło: opracowanie własne. 
Następnie, wykorzystując metodę DEA, zidentyfikowano wzorce efektywności (benchmarki) dla nieefektywnych DMU (wydziałów), na podstawie których wyznaczono kombinację technologii pozwalającą osiagnąć wyższe efekty przy danych nakładach. Obliczenia przeprowadzono na podstawie wartości współczynników kombinacji liniowej technologii wspólnej $-\lambda$ (tabela 3.).

TABELA 3.

Współczynniki kombinacji liniowej $(\lambda)$ technologii wspólnej dla wydziałów

\begin{tabular}{|l|c|c|c|c|}
\hline \multirow{2}{*}{ Wydziały SGGW } & \multicolumn{3}{|c|}{ Efektywne wydziały } \\
\cline { 2 - 5 } & $\begin{array}{c}\text { Medycyny } \\
\text { Weterynaryj- } \\
\text { nej }\end{array}$ & Leśny & $\begin{array}{c}\text { Technologii } \\
\text { Drewna }\end{array}$ & $\begin{array}{c}\text { Nauk Ekono- } \\
\text { micznych }\end{array}$ \\
\hline Rolnictwa i Biologii & 0,45 & 0,60 & 0,05 & 0,32 \\
\hline $\begin{array}{l}\text { Ogrodnictwa, Biotech- } \\
\text { nologii i Architektury } \\
\text { Krajobrazu }\end{array}$ & 0,43 & 0,24 & & 0,11 \\
\hline $\begin{array}{l}\text { Budownictwa i Inżynie- } \\
\text { rii Środowiska }\end{array}$ & 0,46 & 0,03 & & 0,81 \\
\hline Nauk o Zwierzętach & 0,20 & & 0,92 & 0,08 \\
\hline Nauk o Żywności & 0,02 & & 1,80 & 0,21 \\
\hline $\begin{array}{l}\text { Nauk o Żywieniu Czło- } \\
\text { wieka i Konsumpcji }\end{array}$ & & & 0,22 & 0,20 \\
\hline Inżynierii Produkcji & & & & 0,37 \\
\hline Nauk Humanistycznych & & & 0,37 & 0,52 \\
\hline $\begin{array}{l}\text { Zastosowań Informatyki } \\
\text { i Matematyki }\end{array}$ & & & & \\
\hline
\end{tabular}

Źródło: opracowanie własne.

Na przykład dla Wydziału Zastosowań Informatyki i Matematyki jest optymalna kombinacja: 36,65\% technologii Wydziału Technologii Drewna i 52,13\% technologii Wydziału Nauk Ekonomicznych. Wydział Technologii Drewna i Nauk Ekonomicznych stały się punktami odniesienia (tak zwanymi benchmarkami) dla nieefektywnego Wydziału Zastosowań Informatyki i Matematyki. Innymi słowy, Wydział Zastosowań Informatyki i Matematyki, aby stać się efektywnym przy posiadanej liczbie nauczycieli akademickich, powinien generować następujące wielkości efektów:

1. $\mathbf{y}_{1}$ - liczba studentów: $0,3665 \times 635+0,5213 \times 5317=3004$ osób,

2. $\quad y_{2}-$ liczba punktów za publikacje: $0,3665 \times 1348+0,5213 \times 3114=2117$ pkt,

3. $\mathbf{y}_{3}$ - łączna wartość grantów i prac zleconych (KZL): 0,3665×320234,19+ $0,5213 \times 1047386=663368 \mathrm{z}$.

Zatem, biorąc pod uwage powyższe obliczenia, Wydział Zastosowań Informatyki i Matematyki powinien przy danej licznie nauczycieli osiagać o 126\% więcej punktów 
za publikacje, kształcić o 126\% więcej studentów oraz mieć granty i KZL o wartości większej o 165\%. Potencjalne zmiany, jakie powinny dokonać się w zakresie efektów na wydziałach SGGW o efektywności niższej niż 1,00, przedstawiono na rysunku 3. Wyniki sugeruja, że wydziały te, dysponując danym potencjałem ludzkim wyrażonym liczbą nauczycieli akademickich, powinny osiagać wyższe efekty, co pozwoliłoby im poprawić efektywność.

RYSUNEK 3.

\section{Zalecenia dotyczące zwiększenia efektów dla nieefektywnych wydziałów SGGW w Warszawie}

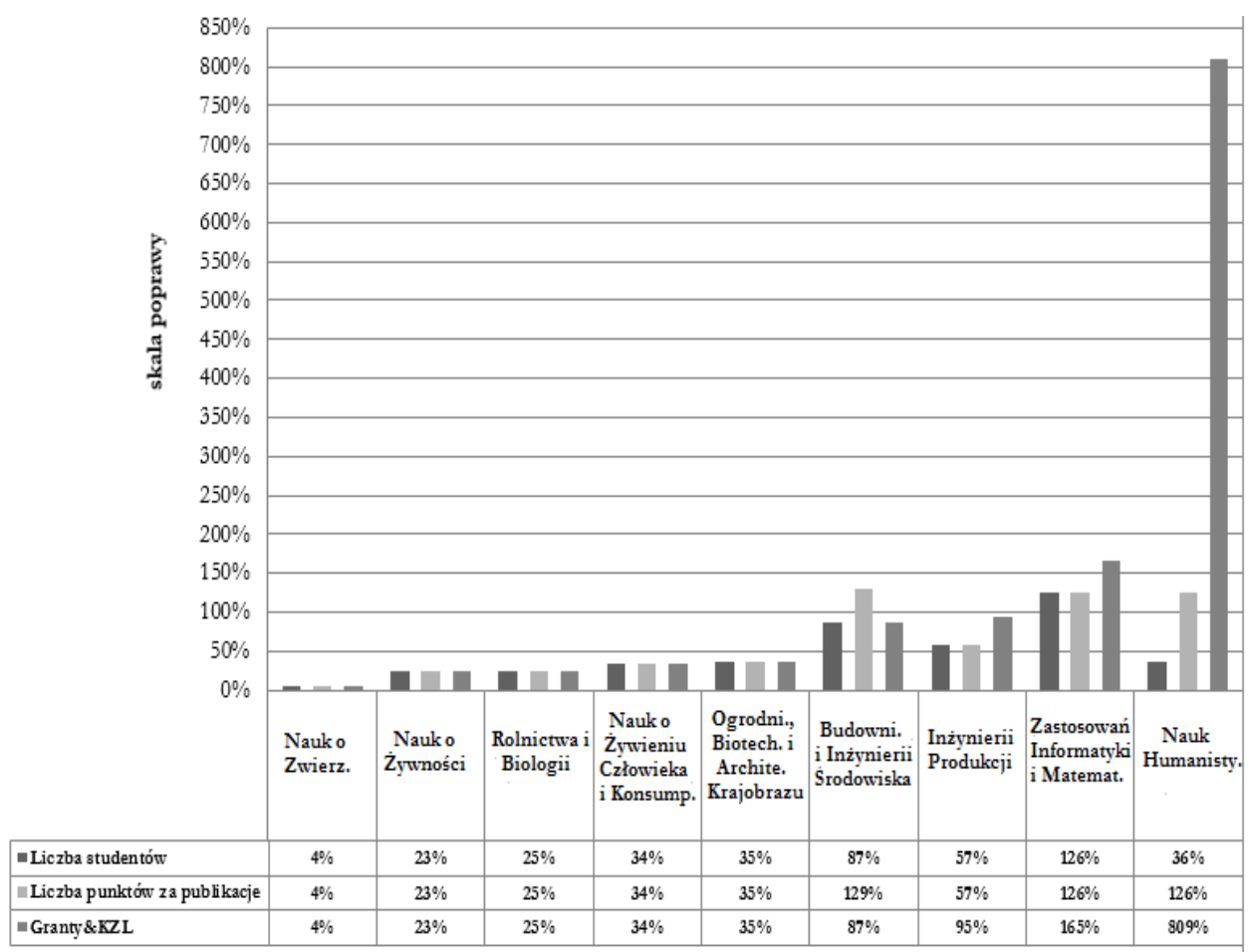

Źródło: opracowanie własne.

\section{Podsumowanie}

Istotą ekonomii jest badanie zachowań ludzi w kontekście efektywności alokacji rzadkich zasobów o alternatywnych zastosowaniach dla realizacji przyjętych celów. Alokacja ta odbywa się nie tylko poprzez rynek, ale również za pośrednictwem sektora publicznego. W wielu krajach obszarem zaangażowania państwa jest edukacja wyższa, którą traktuje się jako dobro merytoryczne. Kluczową kwestią staje się zatem ocena efektywności funkcjonowania podmiotów sektora publicznego, jakimi są publiczne szkoły 
wyższe. Problem ten jest złożony, między innymi ze względu na wielowątkowość misji współczesnego uniwersytetu przedsiębiorczego. Z tego punktu widzenia pomocnym narzędziem w pomiarze efektywności może okazać się metoda DEA umożliwiająca uchwycenie wielu wymiarów efektywności dzięki jednoczesnemu uwzględnieniu kilku efektów i kilku nakładów. Zastosowanie metody DEA w pilotażowych badaniach efektywności wydziałów SGGW w Warszawie pozwoliło na zidentyfikowanie jednostek efektywnych i nieefektywnych oraz umożliwiło za pomocą benchmarkingu ukazanie kierunków i skali możliwej poprawy efektywności.

Oczywiście, należy pamiętać o ograniczeniach przeprowadzonych badań, jak i samej metody. Przeprowadzone badania dotyczyły tylko jednej uczelni i zaledwie 13 wydziałów - bazują więc na skromnym zakresie materiału empirycznego. Spowodowało to konieczność kompromisu w zakresie liczby uwzględnionych zmiennych, przy czym dodatkowym ograniczeniem była dostępność danych w zakresie potencjalnych nakładów i efektów. W efekcie główna zaleta metody DEA, którą jest badanie efektywności przy uwzględnieniu wielu nakładów i wielu efektów, była wykorzystana w ograniczonym zakresie. Dodatkowo jeden z efektów został wyrażony w kategoriach wartościowych, co sprawia, że uzyskany wynik analizy DEA nie jest już czystą postacią efektywności technicznej.

Trzeba także pamiętać o ograniczeniach metody DEA m.in. takich jak: duża wrażliwość wyników na błędne lub nietypowe dane w obiektach uznanych za efektywne (co przypadku różnorodnej specyfiki wydziałów jest prawdopodobne), względny charakter efektywności obiektu (np. może się również zdarzyć, że obiekt o niezbyt dużej sprawności zostanie uznany za w pełni efektywny - gdyż inni są jeszcze gorsi, taka sytuacja nie występuje przy stosowaniu wskaźników finansowych), wrażliwość na liczbę uwzględnionych nakładów i efektów (im większa liczba zmiennych, tym większa możliwość znalezienia się na granicy efektywności jednostki w rzeczywistości nieefektywnej).

Zatem jest wskazana kontynuacja badań nad efektywnością wydziałów i uczelni publicznych, w tym przy zastosowaniu metody DEA. Warto w tym zakresie uwzględniać możliwie duże, ale jednocześnie jednorodne próby badawcze. Umożliwi to stosowanie większej liczby zmiennych po stronie efektów i nakładów, a jednocześnie pozwoli uniknąć problemów wynikających z wrażliwości na nietypowe dane. Poza tym warto weryfikować wyniki uzyskane metodą DEA przy użyciu innych metod, aczkolwiek nie jest to łatwe, gdyż nie istnieja powszechnie uznawane miary pozwalające jednoznacznie określić efektywność danej uczelni czy wydziału.

\section{Literatura}

Ansoff H. I. 1985 Zarzqdzanie strategiczne, Państwowe Wydawnictwo Ekonomiczne, Warszawa.

Bates J. M. 1993 The efficiency of local education authorities, „Oxford Review of Education”, no. 19(3).

Bowden E. V., Bowden J. H. 2002 Ekonomia. Nauka zdrowego rozsadku, Fundacja Innowacja, Warszawa. 
Celik O., Ecer A. 2009 Efficiency in accounting education: evidence from Turkish Universities, „Critical Perspectives on Accounting”, no. 20.

Chakraborty K., Biswas B., Lewis W. C. 2001 Measurement of technical efficiency in public education: $A$ stochastic and nonstochastic production function approach, „Southern Economic Journal", no. 67(4).

Charnes A., Cooper W.W., Rhodes E. 1981 Evaluating Program and Managerial Efficiency: An Application of Data Envelopment Analysis to Program Follow Through, „Management Science", no. 27.

Charnes A., Cooper W. W., Lewin A. Y., Seiford L. M. 1994 Data Envelopment Analysis: Theory, Methodology and Application, Kluwer Academic Publishers, Boston - Dordrecht - Londyn.

Coase R. 2013 Firma, rynek i prawo, OficynaWolters Kluwer Business, Warszawa.

Cooper W.W., Seiford L. M., Tone K. 2007 Data Envelopment Analysis: A Comprehensive Text with Models, Applications, References and DEA-Solver Software, Kluwer Academic Publishers, Boston.

Ćwiąkała-Małys A. 2009 Pomiar efektywności procesu kształcenia w publicznym sælkolnictwie akademickim, Wydawnictwo Uniwersytetu Wrocławskiego, Wrocław.

Färe R., Grosskopf S., Lindgren B., Roos P. 1992 Productivity changes in Swedish pharmacies 1980-1989. A non-parametric Malmquist approach, ,Journal of Productivity Analysis", no. 3(1).

Fijor J. M. 2011 Cyy dobra public₹ne sq naprawde publicæne?, „Studia Ekonomiczne. Economic Studies", no. 1(68).

Gorynia M., Jaworska B., Owczarzak R. 2005 Zarzqadzanie strategiczne jako próba syntęy teorii przedsiebbiorstwa, „Ekonomista”, nr 5.

Guzik B. 2009 Podstawowe modele DE $A$ w badanin efektywności gospodarczej i społecznej, Wydawnictwo Uniwersytetu Ekonomicznego w Poznaniu, Poznań.

Hollingsworth B., Dawson P., Maniadakis N. 1999 Measurement of health care. A review of nonparametric methods and applications, „Health Care Management Science”, no. 2(3).

Hood Ch. 1991 A Public Management for All Seasons?, „Public Administration”, no. 69.

Jacobs R. 2001 Alternative Methods to Examine Hospital Efficiency: Data Envelopment Analysis and Stochastic Frontier Analysis, „Health Care Management Science”, no. 4.

Johnes J., Yu L. 2008 Measuring the research performance of Chinese higher education institutions using data envelopment analysis, „China Economic Review”, no. 19.

Kao C., Hung H.-T. 2008 Efficiency analysis of university departments: An empirical study, „Omega”, no. 36.

Leitner K., Prikoszovits J., Schaffhauser-Linzatti M., Stowasser R., Wagner K. 2007 The impact of size and specialization on universities' department performance: a DEA analysis applied to Austrian universities, „Higher Education”, no. 53.

Leja K. 2013 Zarzadżanie uczelniq. Koncepcje i wspótczesne myz̧wania, Oficyna Wolters Kluwer Business, Warszawa.

Mancebon M.J., Bandres E. 1999 Efficiency Evaluation in Secondary Schools: the key role of model specification and of ex post analysis of results, „Education Economics”, no. 7. 
Morawski R.Z. 1999 Kryteria efektywności instytucji akademickich, [w:] Model zarzadzania publiczna instytucja akademicka, Woźnicki J. (red.), Wydawnictwo Instytut Spraw Publicznych, Warszawa.

Mucha J. 2006 Interwencje państwa w systemie opieki zdrowotnej. Racje ekonomiczne, „Polityka Społeczna", nr 7.

Musgrave R. A. 1987 Merit Goods, [in:] The New Palgrave: A Dictionary of Economic. First Edition, Vol. III, Eatwell J., Milgate M., Newman P. (eds.), Palgrave Macmillan, Londyn.

Nazarko J., Komuda M., Kuźmicz K., Szebzda E., Urban J. 2008 Metoda DEA w badaniu efeketywności instytuciji sektora publicznego na prayketadzie sžkót wyższych, „Badania Operacyjne i Decyzje", nr 4.

O'Flynn, J. 2007 From New Public Management to Public Value: Paradigmatic Change and Managerial Implications, „,The Australian Journal of Public Administration”, no. 66.

Parker, L.D. 2012 From Privatised to Hybrid Corporatised Higher Education: A Global Financial Management Discourse, „Financial Accountability \& Management”, no. 28.

Pasewicz W., Świtłyk M. 2010 Zastosowanie DEA do oceny efektymności technicznej driatalności dydaktycznej uczelni publicznych w 2005 roku, „Folia Pomeranae Universitatis Technologiae Stetinensis. Oeconomica”, nr 280.

Pietrzak M. 2013a Potrzeba kontroli zarzadczej w publicznych szkołach wy šsych, [w:] Rachunkowość a controlling, E. Nowak, M. Nieplowicz (red.), Wydawnictwo Uniwersytetu Ekonomicznego we Wrocławiu, Wrocław.

Strategia Szkoly Gtównej Gospodarstwa Wiejskiego w Warsqawie do 2020 roku 2013b, Pietrzak M. (red.), Wydawnictwo SGGW, Warszawa.

Porter M. E. 1992 The Competitive Advantage of Nations, The Macmilan Press, Londyn/Basingstoke.

Powell R. 2005 AQA Advanced Economics, Philip Allan Updates, Londyn.

Roll Y., Hayuth Y. 1993 Port Performance Comparison Applying Data Envelopment Analysis (DEA), „Maritime Policy and Management”, no. 20.

Saunders E. S. 2003 Cost efficiency in ARL academic libraries, „The Bottom Line: Managing Library Finances", no. 16(1).

Schimank U. 2005 New Public Management and the Academic Profession: Reflections on the German Situation, „Minerva”, no. 43.

Sprawozdanie Rektora SGGW prof. dr. bab. Alojzego S Symańskiego z działalności uczৃelni za rok 2012, Wydawnictwo SGGW, Warszawa.

Sun S. 2004 Assessing joint maintenance shops in the Taiwanese army using Data Envelopment Analysis, ,Journal of Operations Management”, no. 22(3).

Szkoly wy ższe i ich finanse 2011, Wydawnictwo GUS, Warszawa.

Świtlyk M., Pasewicz W. 2009 Efektywność techniczna ksztatcenia w państwowych uy ższych szkotach zawodowych w latach 2004-2006, „Folia Pomeranae Universitatis Technologiae Stetinensis. Oeconomica”, nr 273.

Tahar, S. 2013 Resource Allocation in Higher Education in The Context of New Public Management, „Public Management Review”, no. 15.

Thanassoulis E., Dunstan P. 1994 Guiding Schools to Improved Performance Using Data Envelopment Analysis: An Illustration with Data from a Local Education Authority, ,Journal of the Operational Research Society", no. 45. 
Warning S. 2004 Performance differences in German higher education: empirical analysis of strategic group, „Review of Industrial Organization”, no. 24.

Wilkesman U., Schmid Ch. J. 2012 The Impacts of New Governance on Teaching at Germany Universities. Findings from a NationalSurvey, ,HigherEducation”, no. 63.

Wolszczak-Derlacz J. 2013 Efektywność naukowa, dydaktyczna i wdrożeniowa publicznych szkót uy issyych w Polsce - analiza nieparametrycz̨na, Wydawnictwo Politechniki Gdańskiej, Gdańsk 2013. 